Prepared in cooperation with the U.S. Air Force Academy

\title{
Bathymetry of Deadmans Lake, Golf Course Reservoir 9, Ice Lake, Kettle Lakes 1-3, and Non-Potable Reservoirs 1-4 at the U.S. Air Force Academy, Colorado, 2019
}

By Michael S. Kohn and Laura A. Hempel

Pamphlet to accompany

Scientific Investigations Map 3463

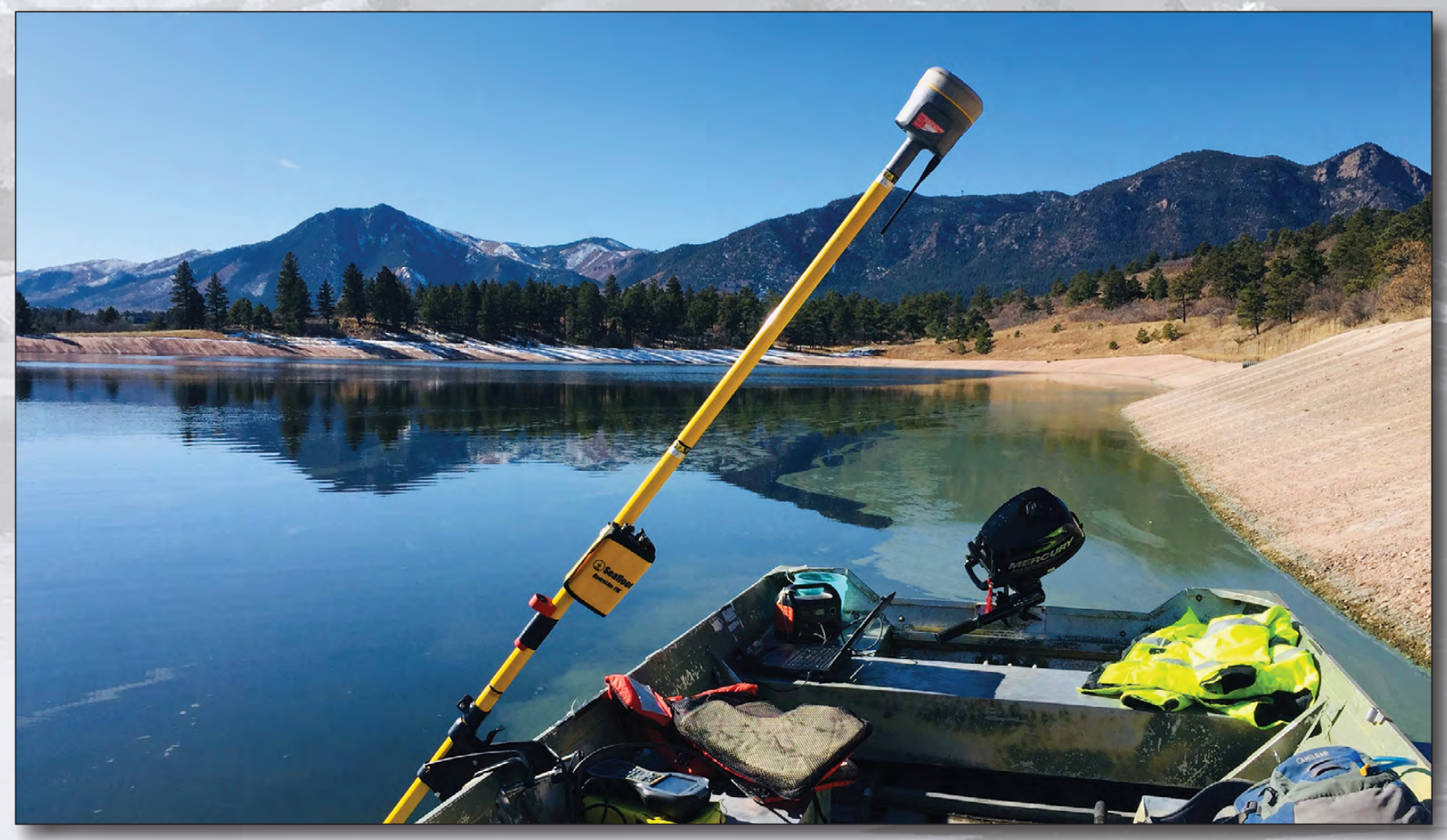

2020

U.S. Department of the Interior

U.S. Geological Survey 


\title{
U.S. Department of the Interior \\ DAVID BERNHARDT, Secretary
}

\author{
U.S. Geological Survey \\ James F. Reilly II, Director
}

U.S. Geological Survey, Reston, Virginia: 2020

For more information on the USGS - the Federal source for science about the Earth, its natural and living resources, natural hazards, and the environment—visit https://www.usgs.gov or call 1-888-ASK-USGS.

For an overview of USGS information products, including maps, imagery, and publications,

visit https://store.usgs.gov.

Any use of trade, firm, or product names is for descriptive purposes only and does not imply endorsement by the U.S. Government.

Although this information product, for the most part, is in the public domain, it also may contain copyrighted materials as noted in the text. Permission to reproduce copyrighted items must be secured from the copyright owner.

Suggested citation:

Kohn, M.S., and Hempel, L.A., 2020, Bathymetry of Deadmans Lake, Golf Course Reservoir 9, Ice Lake, Kettle Lakes 1-3, and Non-Potable Reservoirs 1-4 at the U.S. Air Force Academy, Colorado, 2019: U.S. Geological Survey Scientific Investigations Map 3463, pamphlet 12 p., https://doi.org/10.3133/sim3463.

Associated data for this publication:

Kohn, M.S., and Hempel, L.A., 2020, Survey and bathymetric data of Deadmans Lake, Golf Course Reservoir 9, Ice Lake, Kettle Lakes 1-3, and Non-Potable Reservoirs 1-4 at the U.S. Air Force Academy, Colorado, 2019 (ver. 1.1, June 2020): U.S. Geological Survey data release, https://doi.org/10.5066/PgLTHORO.

ISSN 2329-132X (online)

Cover. Non-Potable Reservoir 2 at the U.S. Air Force Academy near Colorado Springs, Colorado, looking west on November 12, 2019, during bathymetric data collection. Photograph by Laura Hempel, U.S. Geological Survey. 


\section{Acknowledgments}

The authors would like to thank Kirk Weiss, of the U.S. Air Force Academy, for his support and coordination of the study. The authors are also grateful to Trevor Weiland, of the U.S. Air Force Academy, for providing the light detection and ranging (LiDAR) data that was used to supplement data collected in the study.

The authors would also like to recognize the following U.S. Geological Survey staff for their assistance with the data collection: Garrett A. Akie, Emily A. Baker, Rick M. Clawges, Ryan P. Dunn, John W. Fulton, Andrew C. Klakulak, and William R. McDermott.

\section{Contents}

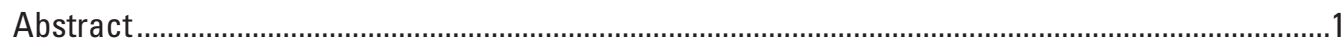

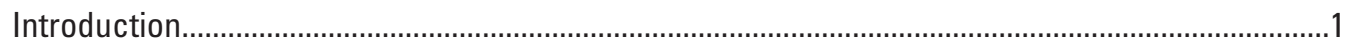

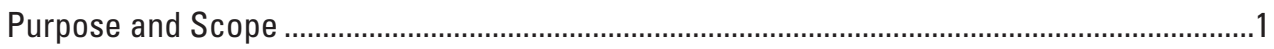

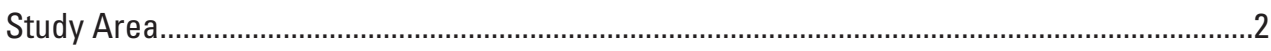

Methods.

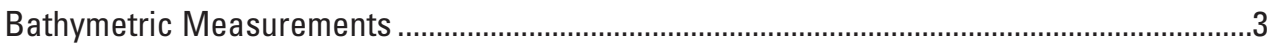

Postprocessing and Data Analysis .......................................................................................

Bathymetry of Lakes and Reservoirs.....................................................................................

Summary.

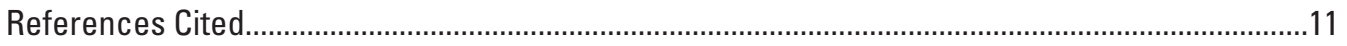

\section{Figures}

1. Map of the study area at the U.S. Air Force Academy near Colorado Springs, Colorado. on map sheet

2. Elevation-volume curve of Deadmans Lake, U.S. Air Force Academy, Colorado, 2019

3. Elevation-volume curve of Golf Course Reservoir 9, U.S. Air Force Academy,

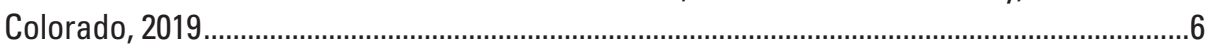

4. Elevation-volume curve of Ice Lake, U.S. Air Force Academy, Colorado, 2019.....................6

5. Elevation-volume curve of Kettle Lake 1, U.S. Air Force Academy, Colorado, 2019..............7

6. Elevation-volume curve of Kettle Lake 2, U.S. Air Force Academy, Colorado, 2019..............7

7. Elevation-volume curve of Kettle Lake 3, U.S. Air Force Academy, Colorado, 2019.............8

8. Elevation-volume curve of Non-Potable Reservoir 1, U.S. Air Force Academy,

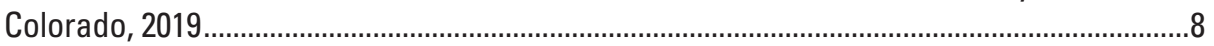

9. Elevation-volume curve of Non-Potable Reservoir 2, U.S. Air Force Academy, Colorado, 2019.

10. Elevation-volume curve of Non-Potable Reservoir 3, U.S. Air Force Academy, Colorado, 2019.

11. Elevation-volume curve of Non-Potable Reservoir 4, U.S. Air Force Academy, Colorado, 2019. 


\section{Tables}

1. Uncertainty in the digital elevation models for Deadmans Lake, Golf Course Reservoir 9, Ice Lake, Kettle Lakes 1-3, and Non-Potable Reservoirs 1-4,

U.S. Air Force Academy, Colorado, 2019 4

2. Elevation of the spillway crest, main outlet structure, dam crest, and top of outlet tower for Deadmans Lake, Golf Course Reservoir 9, Ice Lake, Kettle Lakes 1-3, and Non-Potable Reservoirs 1-4, U.S. Air Force Academy, Colorado, 2019. .5

3. Water-surface elevations and volumes of Deadmans Lake, Golf Course Reservoir 9, Ice Lake, Kettle Lakes 1-3, and Non-Potable Reservoirs 1-4, U.S. Air Force Academy, Colorado, during the bathymetric survey, fall 2019 .....

\section{Conversion Factors}

U.S. customary units to International System of Units

\begin{tabular}{lcl}
\hline \multicolumn{1}{c}{ Multiply } & By & \multicolumn{1}{c}{ To obtain } \\
\hline foot (ft) & Length & \\
foot (ft) & 0.3048 & meter (m) \\
U.S. survey foot (sft) & 0.999998000000 & U.S. survey foot (sft) \\
U.S. survey foot (sft) & 0.30480060960122 & meter (m) \\
mile (mi) & 1.000002000004 & foot (ft) \\
& 1.609 & kilometer $(\mathrm{km})$ \\
\hline acre & Area & \\
acre & 4,047 & square meter $\left(\mathrm{m}^{2}\right)$ \\
acre & 0.4047 & hectare (ha) \\
acre & 0.4047 & square hectometer $\left(\mathrm{hm}^{2}\right)$ \\
\hline & 0.004047 & square kilometer $\left(\mathrm{km}^{2}\right)$ \\
\hline acre-foot (acre-ft) & Volume & \\
acre-foot (acre-ft) & 1,233 & cubic meter $\left(\mathrm{m}^{3}\right)$ \\
\hline
\end{tabular}




\section{Datum}

Vertical coordinate information is referenced to the North American Vertical Datum of 1988 (NAVD 88), referenced to GEOID18.

Horizontal coordinate information is referenced to the North American Datum of 1983 (NAD 83), State Plane Colorado Central.

Elevation, as used in this report, refers to distance above the vertical datum.

\section{Abbreviations}

$\begin{array}{ll}\text { DEM } & \text { digital elevation model } \\ \text { GLONASS } & \text { GLObal NAvigation Satellite System } \\ \text { GNSS } & \text { Global Navigation Satellite Systems } \\ \text { GPS } & \text { Global Positioning System } \\ \text { LiDAR } & \text { light detection and ranging } \\ \text { NAD 83 } & \text { North American Datum of 1983 } \\ \text { NAVD 88 } & \text { North American Vertical Datum of 1988 } \\ \text { NGVD 29 } & \text { National Geodetic Vertical Datum of 1929 } \\ \text { OPUS } & \text { Online Positioning User Service } \\ \text { RMSE } & \text { root-mean square error } \\ \text { RTK } & \text { Real-Time Kinematic } \\ \text { USAFA } & \text { U.S. Air Force Academy } \\ \text { USGS } & \text { U.S. Geological Survey }\end{array}$




\title{
Bathymetry of Deadmans Lake, Golf Course Reservoir 9, Ice Lake, Kettle Lakes 1-3, and Non-Potable Reservoirs 1-4 at the U.S. Air Force Academy, Colorado, 2019
}

\author{
Michael S. Kohn and Laura A. Hempel
}

\section{Abstract}

The U.S. Geological Survey, in cooperation with the U.S. Air Force Academy (USAFA), carried out bathymetric and topographic surveys to characterize the volume of Deadmans Lake, Golf Course Reservoir 9, Ice Lake, Kettle Lakes 1-3, and Non-Potable Reservoirs 1-4 at the U.S. Air Force Academy, Colorado. Bathymetric maps of each lake and reservoir are presented with figures of the elevation-volume curves. The bathymetric surveys were carried out from October 15, 2019, to December 12, 2019, using a manually operated, boat-mounted, single-beam echo sounder integrated with a Real-Time Kinematic Global Navigation Satellite Systems receiver. Topographic surveys were carried out during the same time period using Real-Time Kinematic Global Navigation Satellite System to collect elevation data at and above the water surface and up to the elevation of the dam or spillway at the time of the surveys. The topographic and bathymetric datasets were imported into Esri ArcMap 10.7.1. The combined survey points were then interpolated into digital elevation models, which were used to determine lake or reservoir volumes that correspond to watersurface elevations between the lakebed and the approximate top of the dam or spillway.

This report provides an updated characterization of storage capacity and improved understanding of present (2019) water capacity in the lakes and reservoirs at the USAFA. In addition, these surveys serve as a baseline that could be compared with future surveys of the lakes and reservoirs. The differences in these and future surveys could then be used to determine sedimentation infill rates and provide estimates of the lifespan of the lakes and reservoirs.

\section{Introduction}

Deadmans Lake, Golf Course Reservoir 9, Ice Lake, Kettle Lakes 1-3, and Non-Potable Reservoirs 1-4 are located at the U.S. Air Force Academy (USAFA), Colorado Springs, Colorado. The lakes and reservoirs are owned and operated by USAFA to supply water for irrigation and recreation (for example, fishing). In 2019, water-resource managers at USAFA wanted to install gages to monitor the stage and volume of the lakes and reservoirs to improve reservoir regulation and operation during periods of drought or high demand. However, before gage installation could begin, updated storage capacity information was required. To characterize the volume of Deadmans Lake, Golf Course Reservoir 9, Ice Lake, Kettle Lakes 1-3, and Non-Potable Reservoirs 1-4, the U.S. Geological Survey (USGS) carried out bathymetric and topographic surveys in the fall of 2019 in cooperation with the USAFA. The bathymetric surveys were supplemented and combined with topographic surveys to determine the elevation-volume curves of each lake and reservoir. This report provides an updated characterization of storage capacity and improved understanding of present (2019) water capacity in the lakes and reservoirs at the USAFA. In addition, these surveys serve as a baseline that could be compared with future surveys of the lakes and reservoirs. The differences in these and future surveys could then be used to determine sedimentation infill rates and provide estimates of the lifespan of the lakes and reservoirs.

\section{Purpose and Scope}

The purpose of this report is to characterize storage capacity information for 10 lakes and reservoirs at the USAFA, Colorado Springs, Colo., which will improve reservoir regulation and operation during periods of drought or high demand so that the lakes and reservoirs can be monitored using stage and volume gages. To that end, this report presents (1) results of the bathymetric and topographic surveys of Deadmans Lake, Golf Course Reservoir 9, Ice Lake, Kettle Lakes 1-3, and NonPotable Reservoirs 1-4; (2) a description of the data collection effort and bathymetric and topographic survey techniques used to survey the lakes and reservoirs; and (3) methods used for postprocessing and data analysis to develop the final bathymetric digital elevation maps and elevation-volume curves and calculated uncertainty estimates in the digital elevations models. Bathymetric maps of each lake and reservoir are presented with elevation-volume curves. A digital elevation model derived 
from light detection and ranging (LiDAR) data was used in the postprocessing analysis and was collected in 2019 and supplied by USAFA.

\section{Study Area}

The 10 lakes and reservoirs surveyed for this report are in El Paso County, located in central Colorado, at the USAFA in Colorado Springs (fig. 1, on map sheet). The USAFA is located at the base of the Colorado Front Range in the headwaters of the Arkansas River. The USAFA topography varies from prairie grasslands in the east to conifer forest covered foothills in the west; most of the USAFA is undeveloped grasslands or forest with small pockets of development. Monument Creek flows south along the eastern part of the USAFA until its confluence with Fountain Creek, which flows south until its mouth at the Arkansas River. Deadmans Lake is at latitude (lat) $39^{\circ} 01^{\prime} 27^{\prime \prime}$ N. and longitude (long) 104 $53^{\prime} 58^{\prime \prime} \mathrm{W}$. in the northwestern part of the USAFA (U.S. Geological Survey, 2020). Deadmans Lake is created by the impoundment of Deadmans Creek and is located approximately 3.3 miles (mi) upstream from the mouth of Deadmans Creek at the confluence of Monument Creek (U.S. Geological Survey, 2020).

Golf Course Reservoir 9 is at lat $39^{\circ} 00^{\prime} 11^{\prime \prime}$ N. and long $104^{\circ} 52^{\prime} 4^{\prime \prime} \mathrm{W}$. in the west-central part of the USAFA (U.S. Geological Survey, 2020). Golf Course Reservoir 9 is created by the impoundment of Lehman Run and is located approximately 2.8 mi upstream from the mouth of Lehman Run at the confluence of Monument Creek (U.S. Geological Survey, 2020).

Ice Lake is at lat $38^{\circ} 57^{\prime} 24^{\prime \prime} \mathrm{N}$. and long $104^{\circ} 50^{\prime} 06^{\prime \prime} \mathrm{W}$. in the south-central part of the USAFA (U.S. Geological Survey, 2020). Ice Lake is created by an impoundment of a diversion of West Monument Creek and is located approximately $0.1 \mathrm{mi}$ upstream from the mouth of the West Monument Creek diversion at the confluence of Monument Creek (U.S. Geological Survey, 2020).

Kettle Lake 1 is at lat $38^{\circ} 57^{\prime} 41^{\prime \prime}$ N. and $104^{\circ} 48^{\prime} 48^{\prime \prime}$ W. in the southeastern part of the USAFA (U.S. Geological Survey, 2020). Kettle Lake 1 is created by an impoundment of Kettle Creek and is located just downstream from Kettle Lake 2 and approximately $1.3 \mathrm{mi}$ upstream from the mouth of the Kettle Creek at the confluence of Monument Creek (U.S. Geological Survey, 2020).

Kettle Lake 2 is at lat $38^{\circ} 57^{\prime} 47^{\prime \prime} \mathrm{N}$. and long $104^{\circ} 48^{\prime} 42^{\prime \prime}$ W. in the southeastern part of the USAFA (U.S. Geological Survey, 2020). Kettle Lake 2 is created by an impoundment of Kettle Creek and is located just downstream from Kettle Lake 3 , just upstream from Kettle Lake 1, and approximately $1.5 \mathrm{mi}$ upstream from the mouth of the Kettle Creek at the confluence of Monument Creek (U.S. Geological Survey, 2020).

Kettle Lake 3 is at lat $38^{\circ} 57^{\prime} 53^{\prime \prime} \mathrm{N}$. and long $104^{\circ} 48^{\prime} 38^{\prime \prime}$ W. in the southeastern part of the USAFA (U.S. Geological Survey, 2020). Kettle Lake 3 is created by an impoundment of Kettle Creek and is located just upstream from Kettle Lake 2 and approximately $1.6 \mathrm{mi}$ upstream from the mouth of the Kettle Creek at the confluence of Monument Creek (U.S. Geological Survey, 2020).
Non-Potable Reservoir 1 is at lat $39^{\circ} 00^{\prime} 00^{\prime \prime} \mathrm{N}$. and long $104^{\circ} 50^{\prime} 00^{\prime \prime} \mathrm{W}$. in the east-central part of the USAFA (U.S. Geological Survey, 2020). Non-Potable Reservoir 1 is created by the impoundment of Lehman Run and is located approximately 0.2 mi upstream from the mouth of Lehman Run at the confluence of Monument Creek (U.S. Geological Survey, 2020).

Non-Potable Reservoir 2 is at lat $39^{\circ} 00^{\prime} 30^{\prime \prime} \mathrm{N}$. and long $104^{\circ} 51^{\prime} 48^{\prime \prime} \mathrm{W}$. in the central part of the USAFA (U.S. Geological Survey, 2020). Non-Potable Reservoir 2 is a concrete lined reservoir that is created by the impoundment of an unnamed tributary of Monument Creek and is located approximately 2.0 mi upstream from the mouth of the unnamed tributary at the confluence of Monument Creek (U.S. Geological Survey, 2020).

Non-Potable Reservoir 3 is at lat $39^{\circ} 00^{\prime} 5^{\prime \prime} \mathrm{N}$. and long $104^{\circ} 52^{\prime} 15^{\prime \prime} \mathrm{W}$. in the central part of the USAFA (U.S. Geological Survey, 2020). Non-Potable Reservoir 3 is a concrete lined reservoir that is created by the impoundment of an unnamed tributary of Monument Creek and is located approximately $2.5 \mathrm{mi}$ upstream from the mouth of the unnamed tributary at the confluence of Monument Creek (U.S. Geological Survey, 2020).

Non-Potable Reservoir 4 is at lat $39^{\circ} 00^{\prime} 38^{\prime \prime} \mathrm{N}$. and long $104^{\circ} 53^{\prime} 49^{\prime \prime} \mathrm{W}$. in the northwestern part of the USAFA (U.S. Geological Survey, 2020). Non-Potable Reservoir 4 is created by the impoundment of Goat Camp Creek and is located approximately $1.3 \mathrm{mi}$ upstream from the confluence with Deadmans Creek and 3.4 mi upstream from the mouth of Deadmans Creek at the confluence of Monument Creek (U.S. Geological Survey, 2020).

\section{Methods}

All survey data were collected with a common coordinate system, geoid, ellipsoid, and datum. The coordinate system used was State Plane Colorado Central, the geoid was GEOID18, the ellipsoid was World Geodetic System 1984, the horizontal datum was North American Datum of 1983 (NAD 83), and the vertical datum was North American Vertical Datum of 1988 (NAVD 88). The survey data collected resulted in elevationvolume curves in linear units of U.S. survey feet. The U.S. survey foot equals exactly 1,200/3,937 meters (m), where a foot (also referred to as the international foot) equals exactly $0.3048 \mathrm{~m}$ (National Institute of Standards and Technology, 2020).

The bathymetric surveys of Deadmans Lake, Golf Course Reservoir 9, Ice Lake, Kettle Lakes 1-3, and Non-Potable Reservoirs 1-4 were carried out from October 15, 2019, to December 12, 2019, using a manually operated, boat-mounted, single-beam echo sounder integrated with a Real-Time Kinematic (RTK) Global Navigation Satellite Systems (GNSS) receiver. Topographic surveys were carried out during the same time period using RTK GNSS to collect elevation data at and above the water surface and up to the elevation of the dam or spillway at the time of the surveys. A GNSS survey uses both the U.S. Global Positioning System (GPS) satellite network and the Russian GLObal NAvigation Satellite System (GLONASS) satellite network, making it more accurate than a GPS survey, which only uses the U.S. GPS satellite network (Rydlund and 
Densmore, 2012). For the purposes of this report, data collected from both the boat-mounted, single-beam echo sounder integrated with RTK GNSS and the topographic RTK GNSS survey are defined as bathymetric data. The single-beam echo sounder integrated with an RTK GNSS receiver collected data at lake depths of approximately 2 feet (ft) and greater, whereas data collected during the topographic RTK GNSS survey captured the elevation in shallow areas near the shore not navigable by boat and along the shoreline above the water surface.

\section{Bathymetric Measurements}

Bathymetric data from the single-beam echo sounder were collected from October 15-18, 2019, and November 12-15, 2019, using a Seafloor Systems HydroLite-TM single-beam echo sounder (Seafloor Systems, Inc., 2020) equipped with a Trimble R10 GNSS receiver (Trimble Navigation Limited, 2020a) using procedures described in Wilson and Richards (2006) and Rydlund and Densmore (2012). The single-beam echo sounder is rated by the manufacturer to collect bathymetric data at depths from 1.0 to $246 \mathrm{ft}$ with a vertical precision of $\pm 0.033 \mathrm{ft}$ with the data output rate of 2 hertz (Hz) (Seafloor Systems, Inc., 2020). The Trimble R10 GNSS is rated by the manufacturer to collect data with vertical and horizontal precisions of $\pm 0.049 \mathrm{ft}$ and $\pm 0.026 \mathrm{ft}$, respectively, with the data output rate of as much as $20 \mathrm{~Hz}$ (Trimble Navigation Limited, 2020a). The single-beam echo sounder does not account for roll, pitch, and heave of the boat. Therefore, the single-beam echo sounder, which was fixed to a survey rod $6.30 \mathrm{ft}$ below the GNSS receiver, was mounted to the manned boat in a vertical position, and the boat was loaded and operated to maintain the vertical position of the rod. Settings in the Trimble TSC3 data controller were adjusted so that the single-beam echo sounder depths and GNSS position were recorded at 3.28-ft intervals, which corresponded to the square pixel size of digital elevation models (DEMs) (Trimble Navigation Limited, 2020b).

Bathymetric data from the single-beam echo sounder were collected along predefined north-south and east-west transect lines using a 25 -ft spacing between each transect. This was based on a slightly more conservative spacing than the bathymetric survey methods recommended by Wilson and Richards (2006), who stated that the minimum transect interval should be $30 \mathrm{ft}$ because of the practicality of maintaining boat position along the planned transect. The approach used in this study resulted in bathymetric survey points spaced every $3.28 \mathrm{ft}$ within a transect and spaced approximately every $25 \mathrm{ft}$ between north-south and east-west transect lines at depths of approximately $2 \mathrm{ft}$ and greater. During the surveys, the 25 - $\mathrm{ft}$ transect lines were displayed on a laptop computer using the Global Mapper 21.0 (Blue Marble Geographics, Inc., 2020) software package, which was integrated with a Garmin GPS 18x (Garmin International, Inc., 2020). This allowed the operator of the boat to view a real-time display of the boat's position, which ensured bathymetric data was collected along transects spaced $25-\mathrm{ft}$ apart.

The single-beam echo sounder emits an acoustic pulse at a frequency of 200 kilohertz with a beam width of 9 degrees
(Seafloor Systems, Inc., 2020), which was reflected off the lake or reservoir bed, detected by the echo sounder, and converted to a depth below the echo sounder. Calibration-point pairs were collected simultaneously at a subset of locations utilizing measurements from both the topographic RTK GNSS surveying equipment and the single-beam echo sounder. These calibrationpoint pairs provided a measure of discrepancy between the two measurement techniques and were used to ensure bathymetric and topographic data collection processes were consistent.

At each lake and reservoir, the elevations of the dam, spillway, shoreline, main outlet structure (if applicable), top of the outlet tower (if applicable), and shallow areas with depths of $2 \mathrm{ft}$ or less were measured during the topographic RTK GNSS survey following the techniques and methods in Rydlund and Densmore (2012). The topographic RTK GNSS surveys were carried out from October 15-18, 2019, November 12-15, 2019, and December 12, 2019. The topographic RTK GNSS survey collected data points from the top of the dam to a depth of approximately $2 \mathrm{ft}$ along the shoreline at each of the lakes and reservoirs except for Golf Course Reservoir 9, NonPotable Reservoir 1, and Non-Potable Reservoir 4. The dam crest elevation $(6,929.91$ U.S. survey feet $[6,929.92 \mathrm{ft}]$ above NAVD 88) of Golf Course Reservoir 9 was so high that it would have required an extensive survey to the south of the reservoir, so it was decided that surveying 0.50 U.S. survey feet above the spillway elevation (6,927.61 U.S. survey feet [6,927.62 ft] above NAVD 88) would be sufficient because once the reservoir spillway elevation was exceeded the reservoir would begin to empty. The dam elevation (6,584.79 U.S. survey feet [6,584.80 ft] above NAVD 88) at Non-Potable Reservoir 1 was higher than the adjacent terrain to the north and south of the reservoir, so it was decided that surveying up to the south spillway crest elevation (6,579.17 U.S. survey feet [6,579.18 ft] above NAVD 88) would be sufficient because once the reservoir spillway elevation was exceeded the reservoir would begin to empty. The dam elevation (7,209.74 U.S. survey feet [7,209.75 ft] above NAVD 88) at Non-Potable Reservoir 4 was higher to accommodate Academy Drive and would have required an extensive survey upstream from the reservoir, so it was decided by the USGS and USAFA that surveying 0.50 U.S. survey feet above the overflow tower spillway elevation (7,201.99 U.S. survey feet [7,202.00 ft] above NAVD 88) would be sufficient because once the reservoir spillway elevation was exceeded the reservoir would be begin to empty.

The topographic RTK GNSS survey consisted of one base station, which included a Trimble R8 GNSS receiver (Trimble Navigation Limited, 2020c) and Trimble TDL450 radio (Trimble Navigation Limited, 2020d). The topographic RTK GNSS survey consisted of four rovers, each of which consisted of one Trimble R8 or R10 GNSS receiver with an internal radio (Trimble Navigation Limited, 2020a,c) and a Trimble TSC3 or TSC2 data controller (Trimble Navigation Limited, 2020b,e). The topographic and bathymetric surveys used the same base stations, which were located at fixed positions relative to previously surveyed control points throughout USAFA near the lakes and reservoirs. Data collected from the base stations during the surveys were submitted to the National Oceanic and Atmospheric Administration National Geodetic Survey 
Online Positioning User Service (OPUS) website for processing (accessed February 3, 2020, at https:/www.ngs.noaa.gov/ OPUS/). All survey data were recomputed to reflect the OPUS solution correction through a shift in the northing, easting, and elevation.

\section{Postprocessing and Data Analysis}

After the RTK GNSS data were corrected based on the OPUS positions, the topographic and bathymetric datasets were imported into Esri ArcMap 10.7.1 (Esri, 2020). Any data points that appeared erroneous, such as elevation spikes, were manually filtered out of the bathymetric dataset. In total, the singlebeam echo sounder bathymetric dataset consisted of approximately 73,900 individual data points, and the topographic RTK GNSS bathymetric dataset consisted of approximately 19,800 individual data points, resulting in 93,700 total points covering all 10 lakes. For each lake and reservoir, the bathymetric and topographic datasets were merged, resulting in one dataset with a common horizontal and vertical datum (NAD 83 and NAVD 88 ). The combined survey points were then interpolated into a single DEM, composed of 1-U.S. survey foot square pixels, using the Natural Neighbor interpolation tool (Esri, 2020).
Near the reservoir inlet at Non-Potable Reservoir 1, a DEM derived from LiDAR data and composed of 1.00-U.S. survey foot square pixels was merged with the bathymetric DEM to ensure the resultant DEM was continuous below the elevation of the top of the dam. The LiDAR dataset was collected in 2019 and was supplied by USAFA. The LiDAR data for Non-Potable Reservoir 1 used in this report is published in Kohn and Hempel (2020).

The root-mean square error (RMSE) was used to estimate uncertainty in the DEMs (Fisher and Tate, 2006). The RMSE values were calculated in table 1 based on the difference between RTK-GNSS survey-point elevations and collocated DEM pixel elevations (Fisher and Tate, 2006).

Elevations of the spillway crests, main outlet structures (if applicable), dam crests, and tops of outlet towers (if applicable) for Deadmans Lake, Golf Course Reservoir 9, Ice Lake, Kettle Lakes 1-3, and Non-Potable Reservoirs 1-4 were compiled in table 2. Lastly, bathymetric DEMs (map sheet) were used to determine lake or reservoir volumes that correspond to watersurface elevations between the lakebed and the approximate top of the dam or spillway (Esri, 2020). Lake and reservoir volumes were computed at specified elevation ranges using the Surface Volume tool in ArcMap (Esri, 2020) and were compiled into elevation-volume curves (figs. 2-11).

Table 1. Uncertainty in the digital elevation models for Deadmans Lake, Golf Course Reservoir 9, Ice Lake, Kettle Lakes 1-3, and Non-Potable Reservoirs 1-4, U.S. Air Force Academy, Colorado, 2019.

\begin{tabular}{lcccc}
\hline \multicolumn{1}{c}{ Lake or reservoir } & $\begin{array}{c}\text { Root-mean } \\
\text { square error, in } \\
\text { U.S. survey feet }\end{array}$ & $\begin{array}{c}\text { Root-mean } \\
\text { square error, } \\
\text { in feet }\end{array}$ & $\begin{array}{c}\text { Number of data } \\
\text { points per 1-U.S. } \\
\text { survey foot } \\
\text { square pixels }\end{array}$ & $\begin{array}{c}\text { Number of data } \\
\text { points per 1-foot } \\
\text { square pixels }\end{array}$ \\
\hline Deadmans Lake & 0.074 & 0.074 & 0.036 & 0.036 \\
Golf Course Reservoir 9 & 0.124 & 0.124 & 0.074 & 0.074 \\
Ice Lake & 0.043 & 0.043 & 0.033 & 0.033 \\
Kettle Lake 1 & 0.103 & 0.103 & 0.054 & 0.054 \\
Kettle Lake 2 & 0.104 & 0.104 & 0.037 & 0.037 \\
Kettle Lake 3 & 0.144 & 0.144 & 0.032 & 0.032 \\
Non-Potable Reservoir 1 & 0.144 & 0.144 & 0.023 & 0.023 \\
Non-Potable Reservoir 2 & 0.150 & 0.150 & 0.028 & 0.028 \\
Non-Potable Reservoir 3 & 0.097 & 0.097 & 0.021 & 0.021 \\
Non-Potable Reservoir 4 & 0.107 & 0.107 & 0.026 & 0.026 \\
\hline
\end{tabular}

${ }^{a}$ Values represent uncertainty in the merged digital elevation model composed of bathymetric data collected in this study and elevation data derived from light detection and ranging (LiDAR); computed from the combined topographic and bathymetric Real-Time Kinematic Global Navigation Satellite Systems survey points divided by the number of cells in the bathymetric digital elevation models.

${ }^{b}$ LiDAR data that were collected in 2019 and supplied by the U.S. Air Force Academy were used to supplement the bathymetric data collected on the western side of Non-Potable Reservoir 1. 
Table 2. Elevation of the spillway crest, main outlet structure, dam crest, and top of outlet tower for Deadmans Lake, Golf Course Reservoir 9, Ice Lake, Kettle Lakes 1-3, and Non-Potable Reservoirs 1-4, U.S. Air Force Academy, Colorado, 2019.

[NAVD 88, North American Vertical Datum of 1988; NA, not applicable because feature did not exist; NS, not surveyed because feature was submerged beneath the water surface and not accessible]

\begin{tabular}{|c|c|c|c|c|c|c|c|c|}
\hline Lake or reservoir & $\begin{array}{l}\text { Spillway } \\
\text { crest } \\
\text { elevation, } \\
\text { in U.S. } \\
\text { survey feet } \\
\text { (NAVD 88) }\end{array}$ & $\begin{array}{l}\text { Spillway } \\
\text { crest } \\
\text { elevation, } \\
\text { in feet } \\
\text { (NAVD 88) }\end{array}$ & $\begin{array}{l}\text { Main outlet } \\
\text { structure } \\
\text { elevation, } \\
\text { in U.S. } \\
\text { survey feet } \\
\text { (NAVD 88) }\end{array}$ & $\begin{array}{l}\text { Main outlet } \\
\text { structure } \\
\text { elevation, } \\
\text { in feet } \\
\text { (NAVD 88) }\end{array}$ & $\begin{array}{l}\text { Dam crest } \\
\text { elevation, } \\
\text { in U.S. } \\
\text { survey feet } \\
\text { (NAVD 88) }\end{array}$ & $\begin{array}{l}\text { Dam crest } \\
\text { elevation, } \\
\text { in feet } \\
\text { (NAVD 88) }\end{array}$ & $\begin{array}{l}\text { Top of } \\
\text { the outlet } \\
\text { tower } \\
\text { elevation, } \\
\text { in U.S. } \\
\text { survey feet } \\
\text { (NAVD 88) }\end{array}$ & $\begin{array}{l}\text { Top of } \\
\text { the outlet } \\
\text { tower } \\
\text { elevation, } \\
\text { in feet } \\
\text { (NAVD 88) }\end{array}$ \\
\hline Deadmans Lake & NA & NA & $7,187.67$ & $7,187.68$ & $7,190.35$ & $7,190.36$ & NA & NA \\
\hline Golf Course Reservoir 9 & $6,927.61$ & $6,927.62$ & $6,924.23$ & $6,924.24$ & $6,929.91$ & $6,929.92$ & NA & NA \\
\hline Ice Lake & $6,373.30$ & $6,373.31$ & $6,372.14$ & $6,372.15$ & $6,375.17$ & $6,375.18$ & NA & NA \\
\hline Kettle Lake 1 & $6,457.42$ & $6,457.43$ & $6,455.59$ & $6,455.60$ & $6,459.31$ & $6,459.32$ & NA & NA \\
\hline Kettle Lake 2 & NA & NA & $6,474.64$ & $6,474.65$ & $6,481.05$ & $6,481.06$ & NA & NA \\
\hline Kettle Lake 3 & $6,487.68$ & $6,487.69$ & $6,485.21$ & $6,485.22$ & $6,488.09$ & $6,488.10$ & NA & NA \\
\hline Non-Potable Reservoir 1 & $6,573.02^{\mathrm{a}}$ & $6,573.03^{\mathrm{a}}$ & NS & NS & $6,584.79$ & $6,584.80$ & $6,584.13$ & $6,584.14$ \\
\hline Non-Potable Reservoir 2 & $6,898.45$ & $6,898.46$ & NS & NS & $6,902.03$ & $6,902.04$ & $6,904.26$ & $6,904.27$ \\
\hline Non-Potable Reservoir 3 & $6,963.26$ & $6,963.27$ & NS & NS & $6,968.06$ & $6,968.07$ & $6,969.16$ & $6,969.17$ \\
\hline Non-Potable Reservoir 4 & $7,201.99^{\mathrm{b}}$ & $7,202.00^{\mathrm{b}}$ & NS & NS & $7,209.74$ & $7,209.75$ & $7,206.22$ & $7,206.23$ \\
\hline
\end{tabular}

${ }^{a}$ Two spillways are present at Non-Potable Reservoir 1, so values from the lower spillway, the north spillway, are listed here and the south spillway crest is at an elevation of 6,579.17 U.S. survey feet (6,579.18 feet) above NAVD 88.

${ }^{b}$ The spillway was located on the outlet tower above the main outlet structure and was not a separate channel on the ground adjacent to the reservoir.

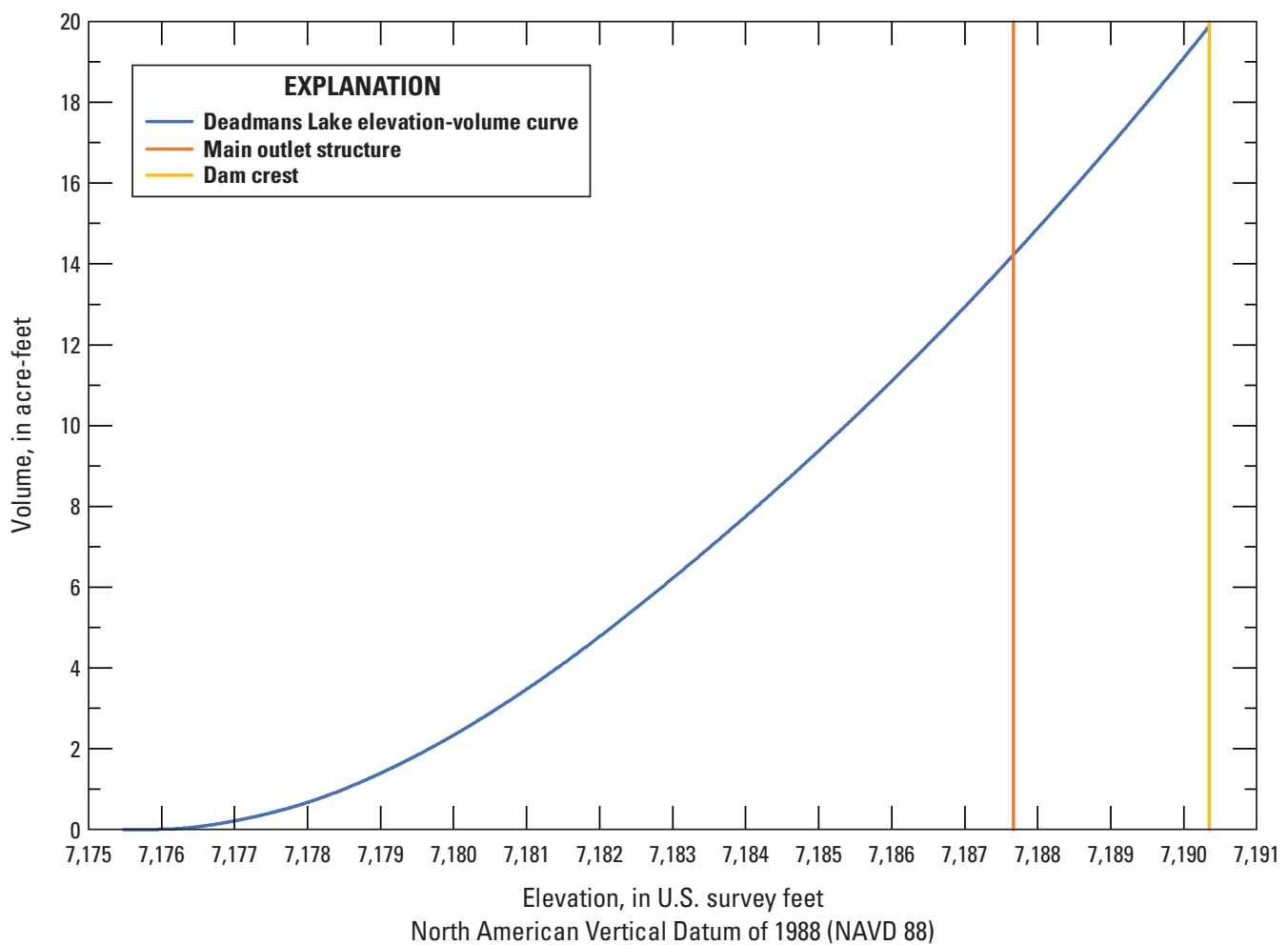

Figure 2. Elevation-volume curve of Deadmans Lake, U.S. Air Force Academy, Colorado, 2019. 


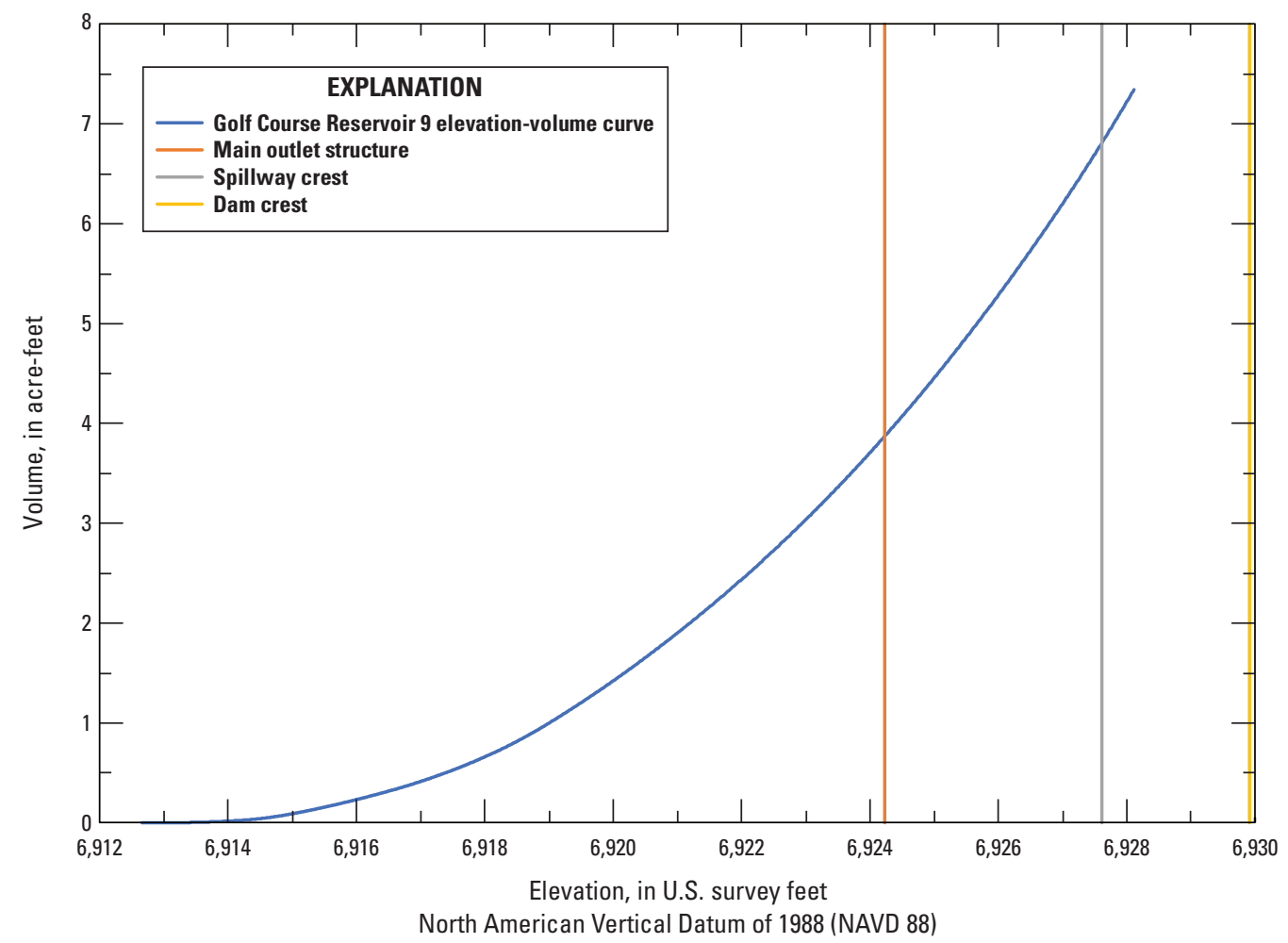

Figure 3. Elevation-volume curve of Golf Course Reservoir 9, U.S. Air Force Academy, Colorado, 2019.

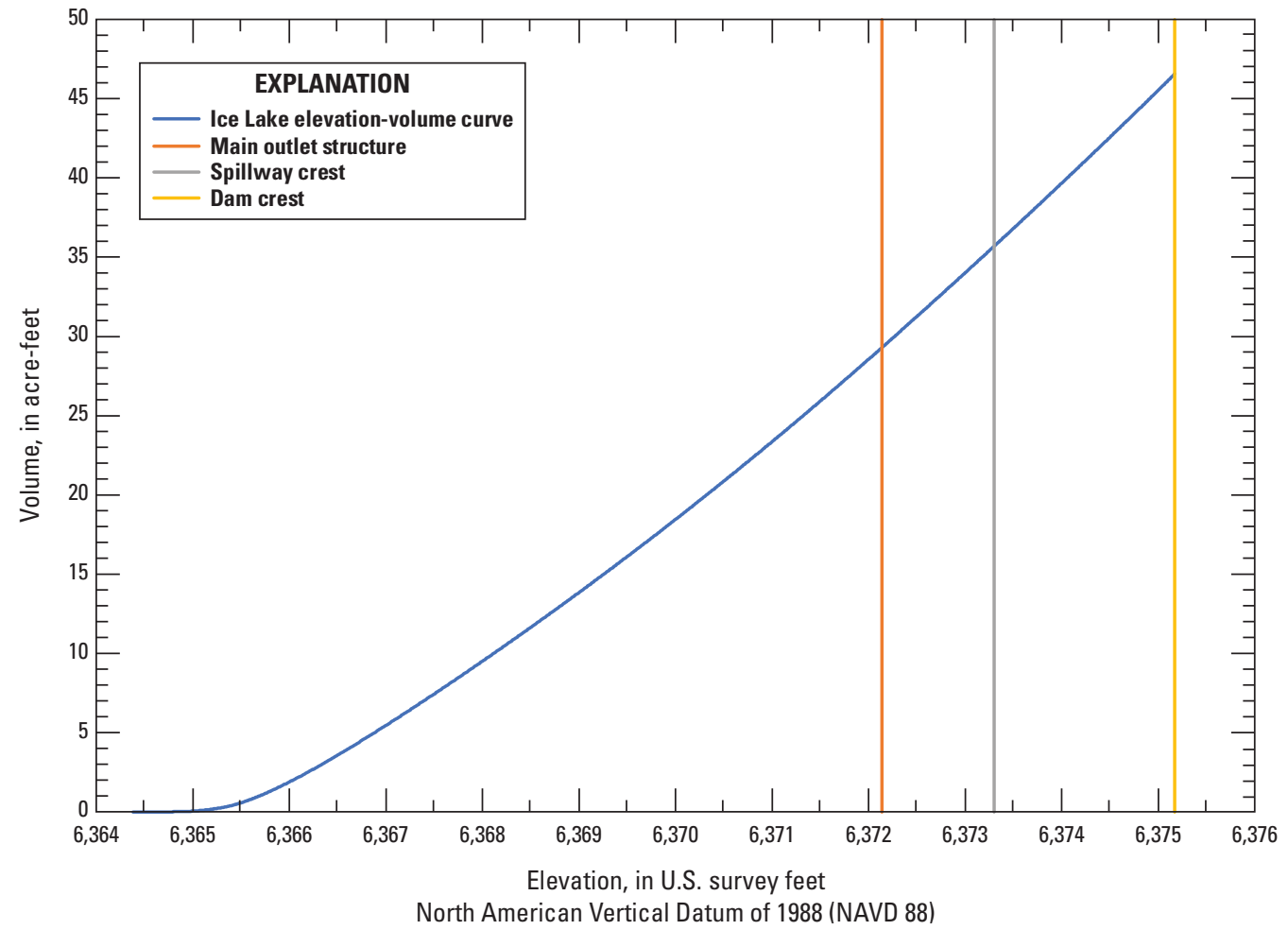

Figure 4. Elevation-volume curve of Ice Lake, U.S. Air Force Academy, Colorado, 2019. 


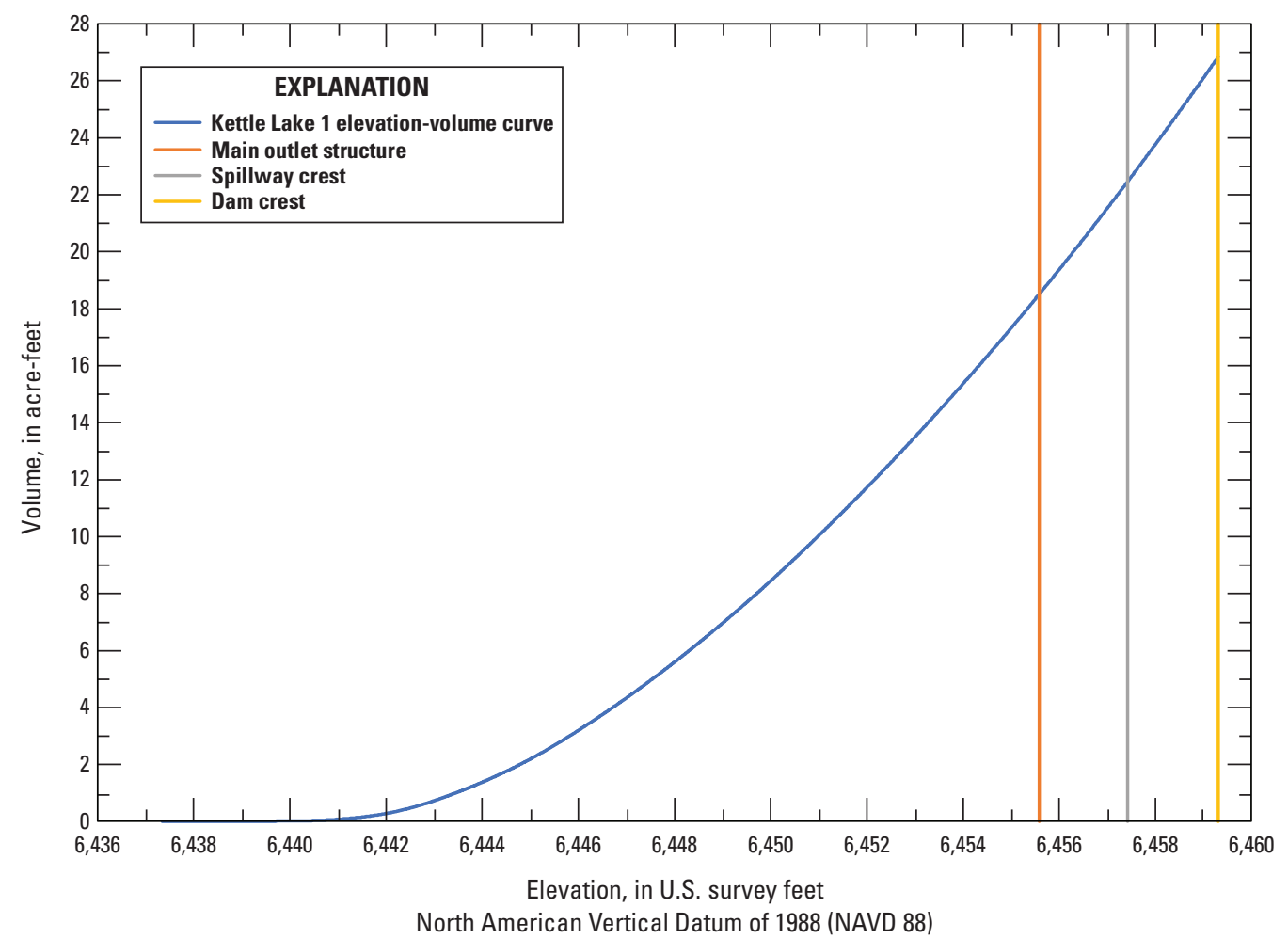

Figure 5. Elevation-volume curve of Kettle Lake 1, U.S. Air Force Academy, Colorado, 2019.

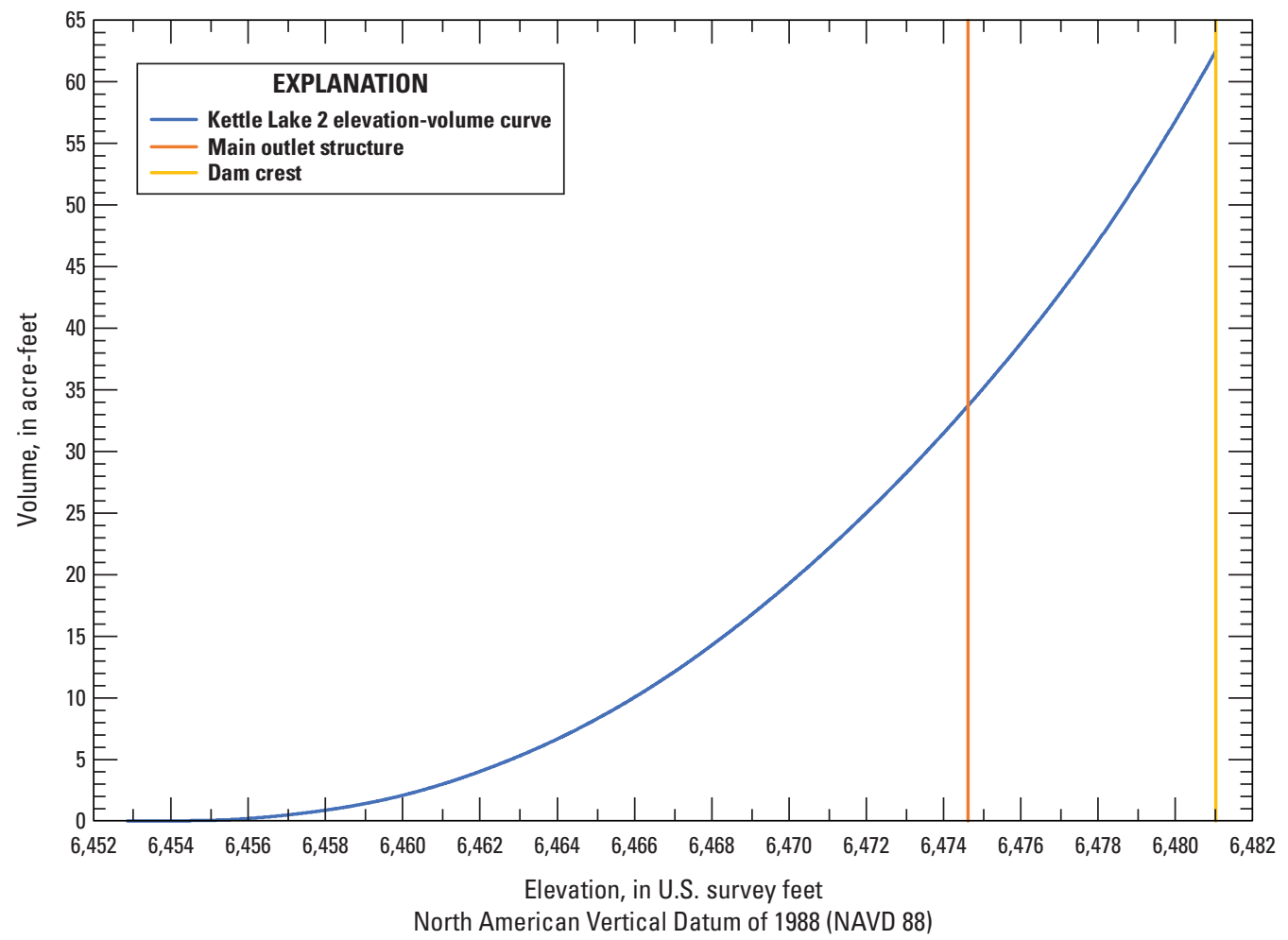

Figure 6. Elevation-volume curve of Kettle Lake 2, U.S. Air Force Academy, Colorado, 2019. 


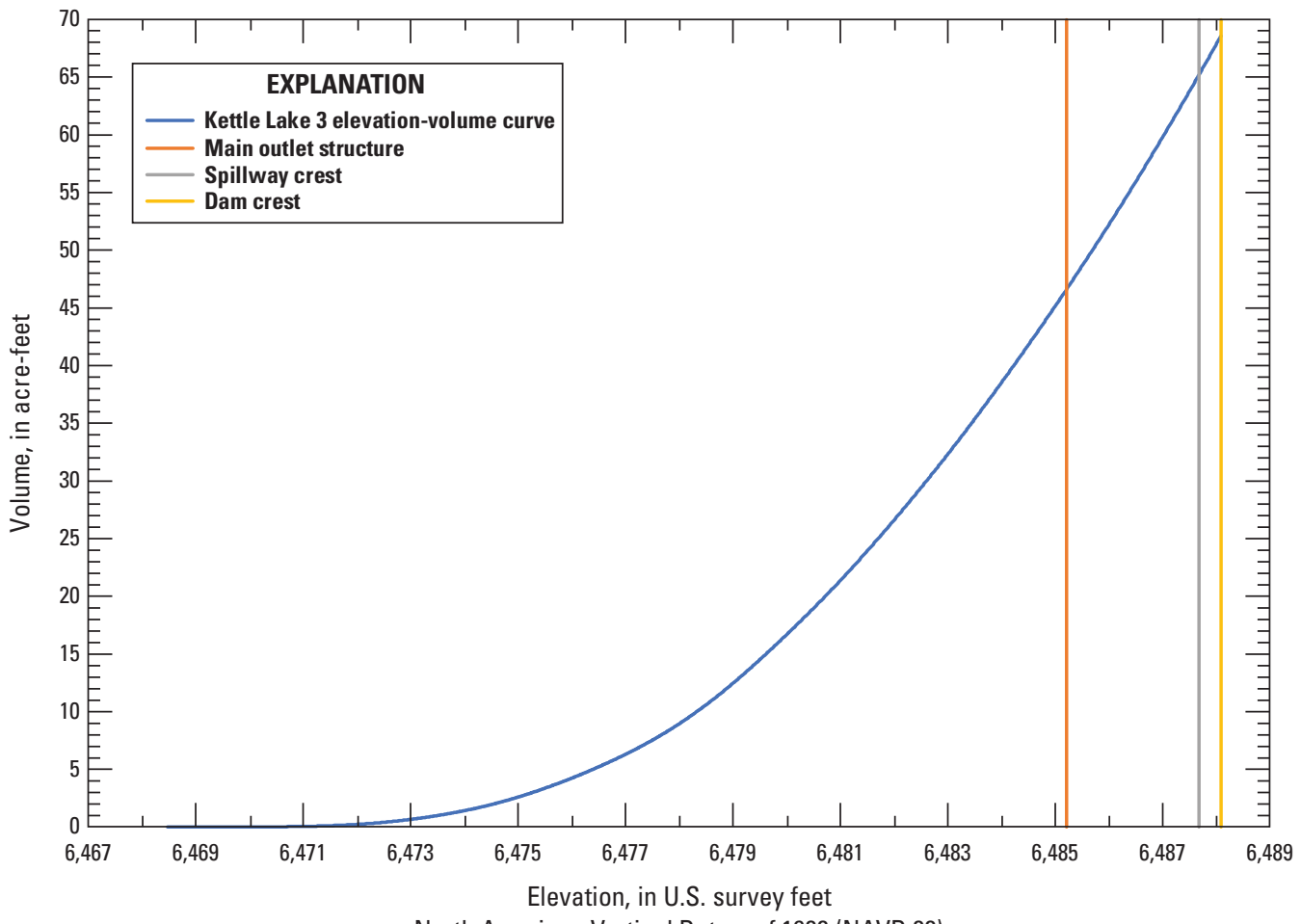

North American Vertical Datum of 1988 (NAVD 88)

Figure 7. Elevation-volume curve of Kettle Lake 3, U.S. Air Force Academy, Colorado, 2019.

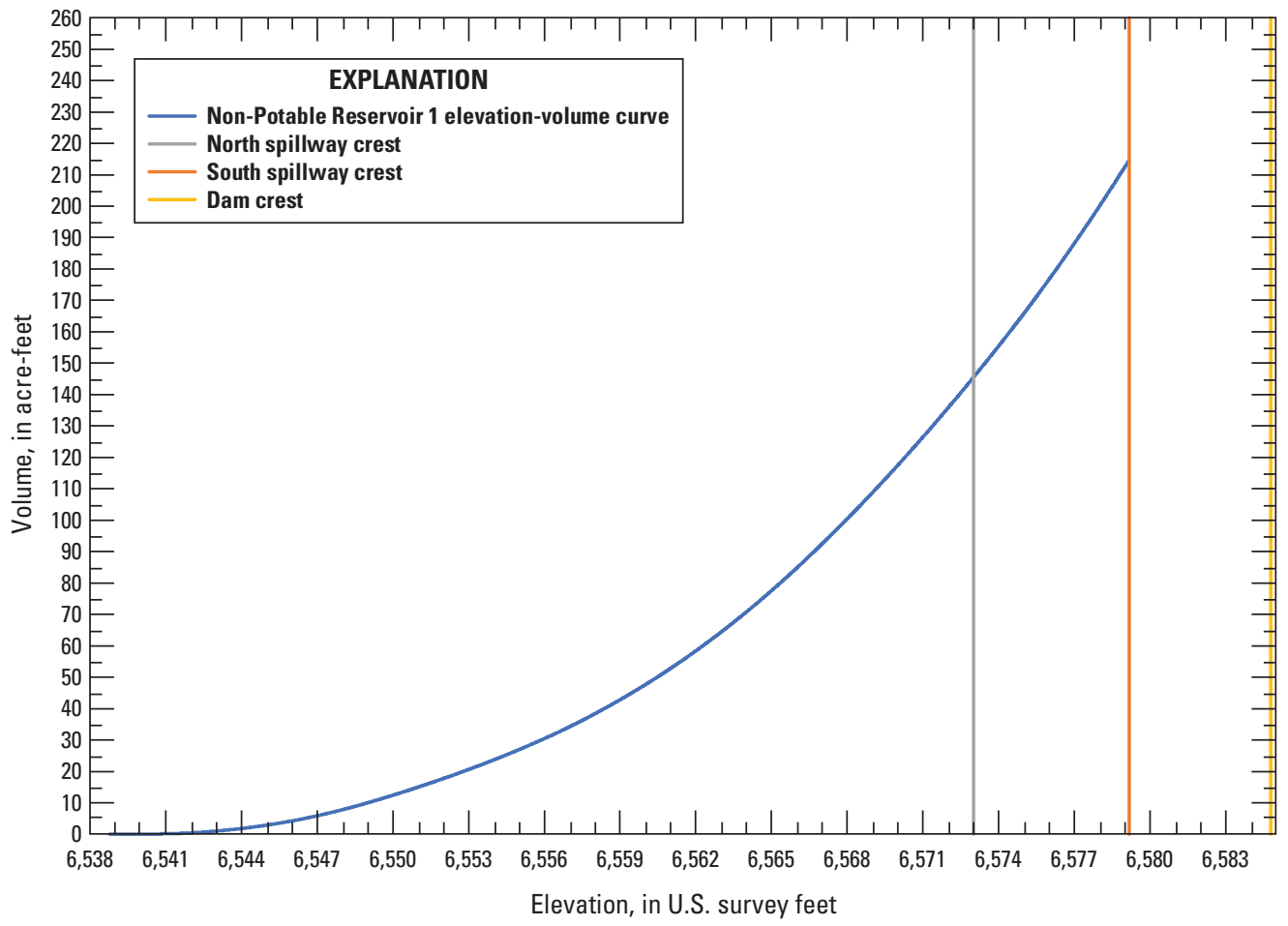

North American Vertical Datum of 1988 (NAVD 88)

Figure 8. Elevation-volume curve of Non-Potable Reservoir 1, U.S. Air Force Academy, Colorado, 2019. 


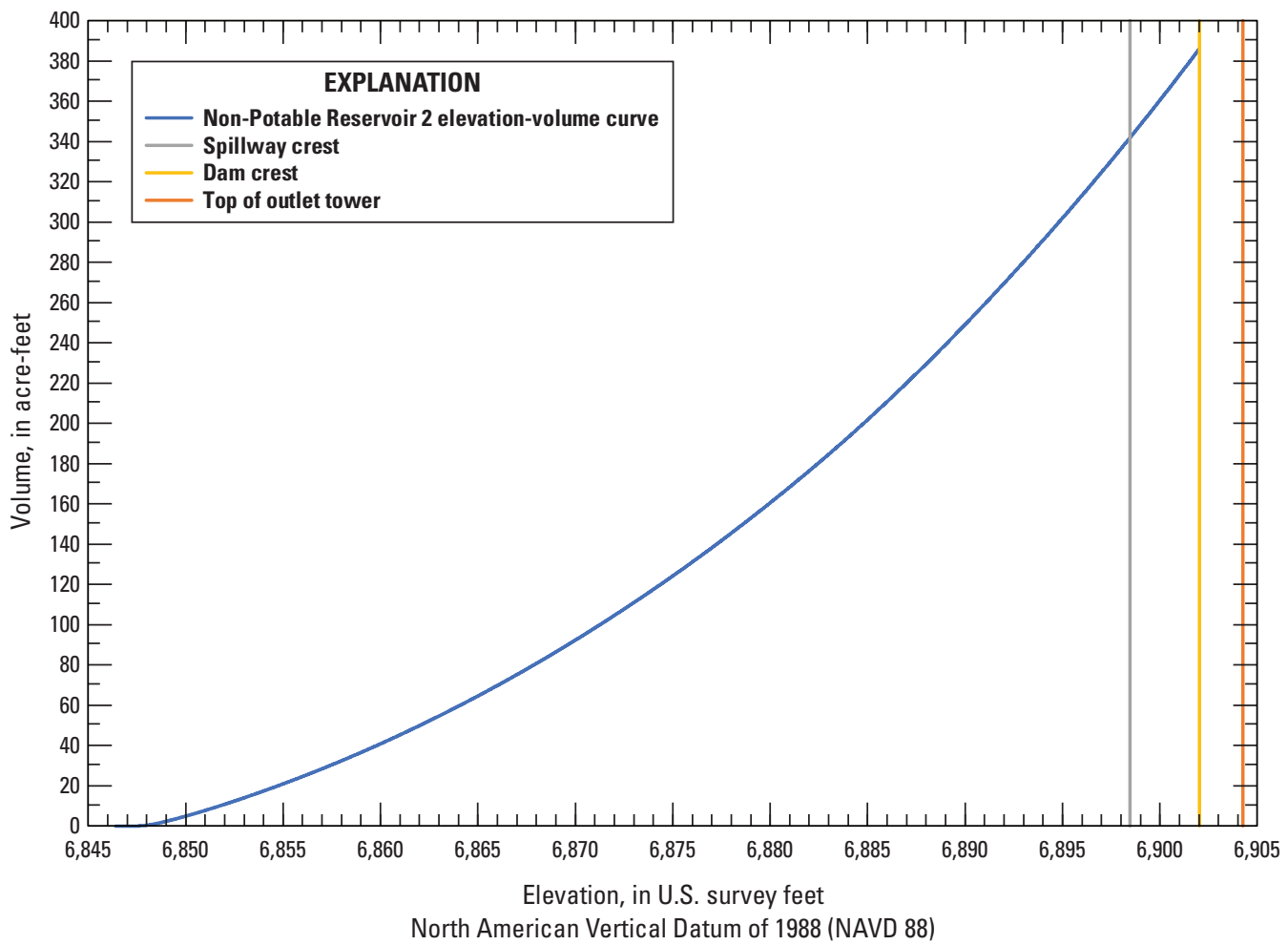

Figure 9. Elevation-volume curve of Non-Potable Reservoir 2, U.S. Air Force Academy, Colorado, 2019.

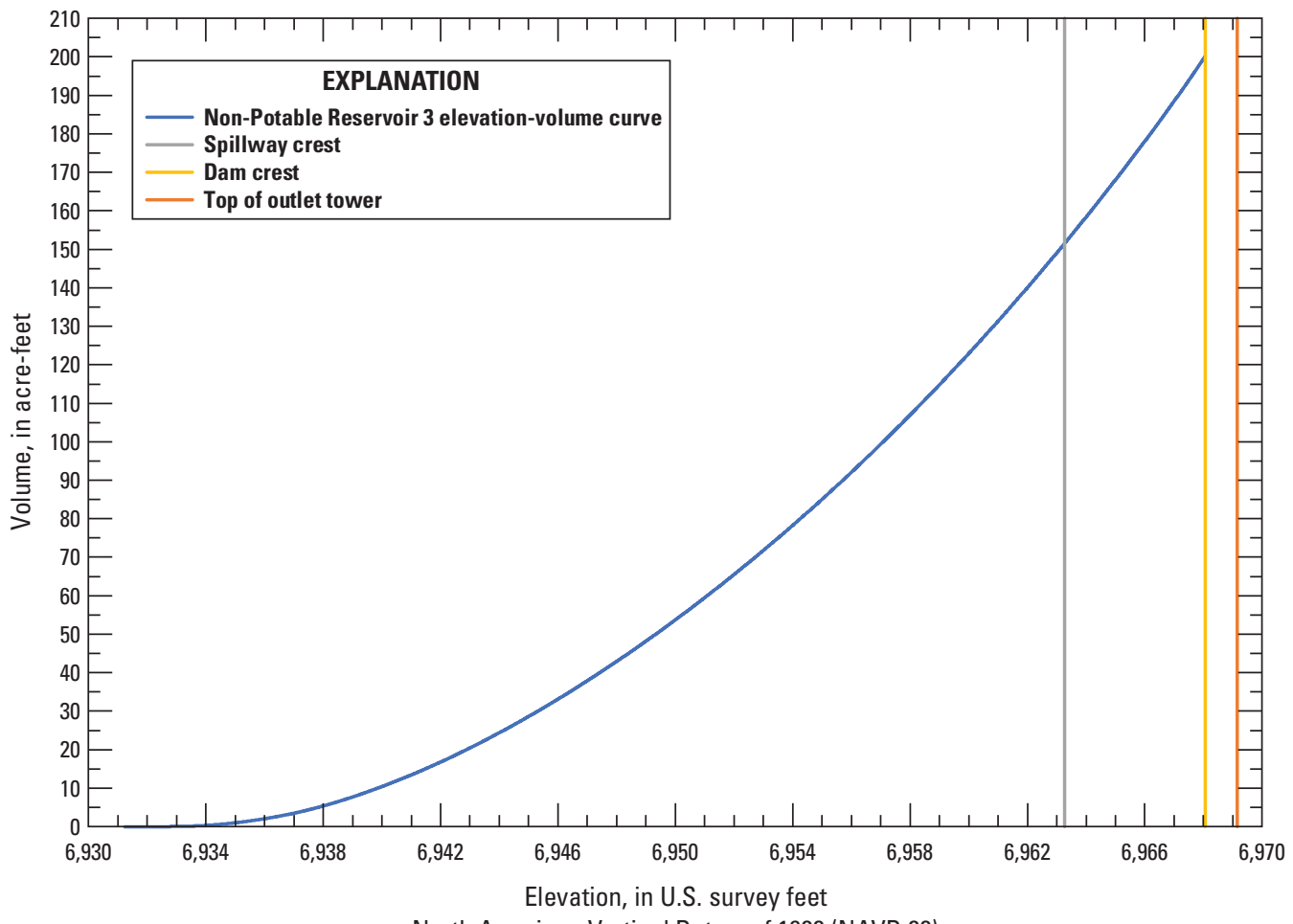

North American Vertical Datum of 1988 (NAVD 88)

Figure 10. Elevation-volume curve of Non-Potable Reservoir 3, U.S. Air Force Academy, Colorado, 2019. 


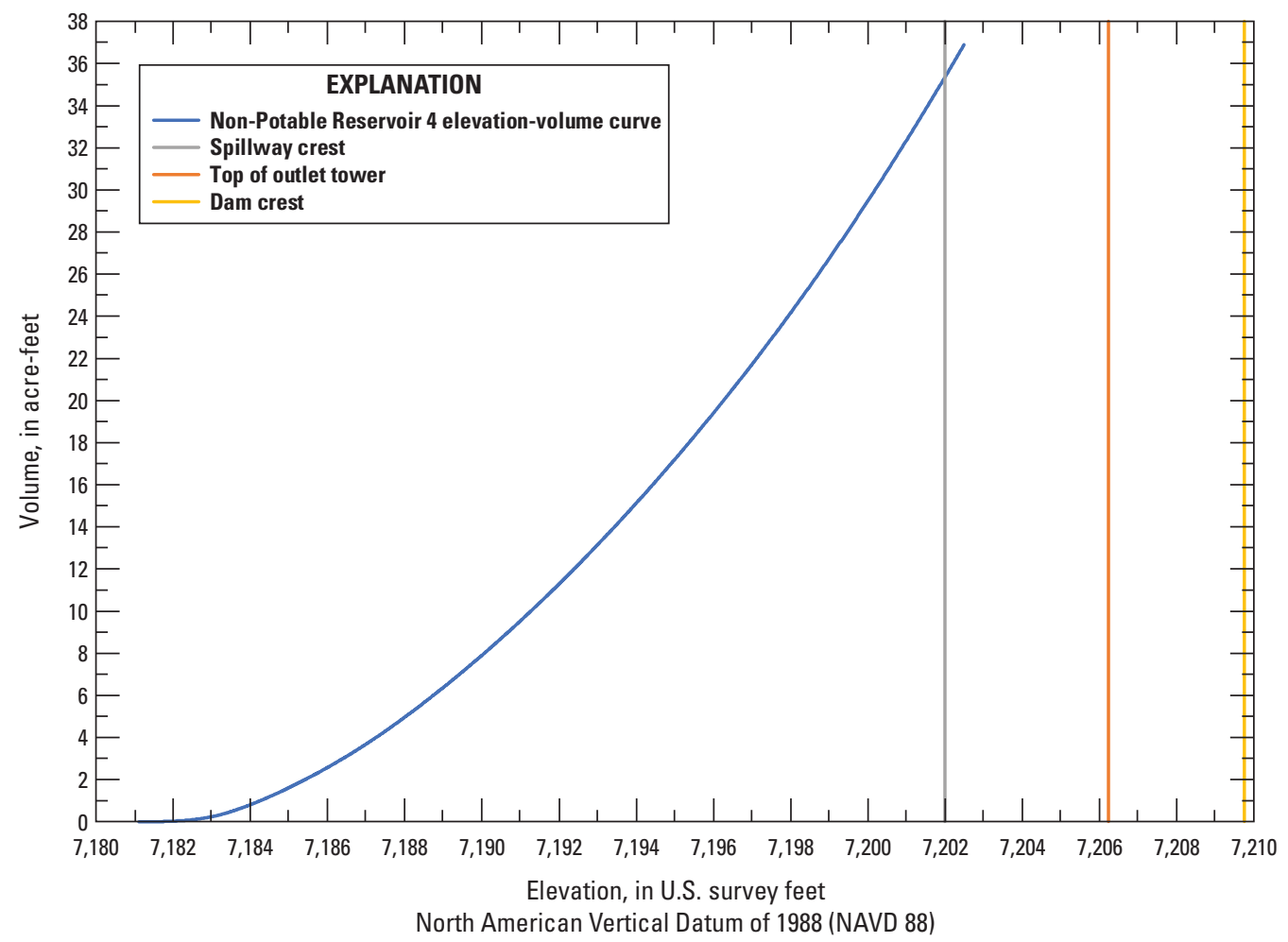

Figure 11. Elevation-volume curve of Non-Potable Reservoir 4, U.S. Air Force Academy, Colorado, 2019.

\section{Bathymetry of Lakes and Reservoirs}

The data for Deadmans Lake, Golf Course Reservoir 9, Ice Lake, Kettle Lakes 1-3, and Non-Potable Reservoirs 1-4 are presented in the following formats.

1. Table 2, which presents the elevations (in NAVD 88) of spillway crests, main outlet structures, dam crests, and tops of outlet towers.

2. Map sheet, which presents bathymetric maps of the features.

3. Figures 2-11, which display elevation-volume curves.

4. Table 3, which presents the water-surface elevations (in NAVD 88) and volumes of each feature at the time of the bathymetric survey.

The elevation and volume data at specified elevations for each lake or reservoir are published in Kohn and Hempel (2020). The combined topographic and bathymetric RTK GNSS survey points and bathymetric DEMs are also published in Kohn and Hempel (2020).

\section{Summary}

The U.S. Geological Survey, in cooperation with the U.S. Air Force Academy (USAFA), carried out bathymetric and topographic surveys to characterize the volume of Deadmans Lake, Golf Course Reservoir 9, Ice Lake, Kettle Lakes 1-3, and Non-Potable Reservoirs 1-4 at the U.S. Air Force Academy, Colorado. This report provides an updated characterization of storage capacity and improved understanding of present (2019) water capacity in the lakes and reservoirs at the USAFA. In addition, these surveys serve as a baseline that could be compared with future surveys of the lakes and reservoirs. The differences in these and future surveys could then be used to determine sedimentation infill rates and provide estimates of the lifespan of the lakes and reservoirs. Bathymetric maps of each lake and reservoir are presented with graphs of the elevation-volume curves. The bathymetric surveys were carried out from October 15, 2019, to December 12, 2019, using a manually operated, boat-mounted, single-beam echo sounder integrated with a Real-Time Kinematic Global Navigation Satellite Systems receiver. Topographic surveys were carried out during the same time period using the Real-Time Kinematic 
Table 3. Water-surface elevations and volumes of Deadmans Lake, Golf Course Reservoir 9, Ice Lake, Kettle Lakes 1-3, and Non-Potable Reservoirs 1-4, U.S. Air Force Academy, Colorado, during the bathymetric survey, fall 2019.

[NAVD 88, North American Vertical Datum of 1988]

\begin{tabular}{llccr}
\hline \multicolumn{1}{c}{ Lake or reservoir } & Date of survey & $\begin{array}{c}\text { Water-surface } \\
\text { elevation during } \\
\text { bathymetric survey, } \\
\text { in U.S. survey feet } \\
\text { (NAVD 88) }\end{array}$ & $\begin{array}{c}\text { Water-surface } \\
\text { elevation during } \\
\text { bathymetric survey, } \\
\text { in feet (NAVD 88) }\end{array}$ & $\begin{array}{c}\text { Volume during } \\
\text { bathymetric survey, } \\
\text { in acre-feet }\end{array}$ \\
\hline Deadmans Lake & November 14, 2019 & $7,184.92$ & $7,184.93$ & 9.24 \\
Golf Course Reservoir 9 & October 15, 2019 & $6,920.83$ & $6,920.84$ & 1.81 \\
Ice Lake & October 18, 2019 & $6,369.53$ & $6,369.54$ & 16.25 \\
Kettle Lake 1 & October 15, 2019 & $6,455.70$ & $6,455.71$ & 18.75 \\
Kettle Lake 2 & October 16, 2019 & $6,474.69$ & $6,474.70$ & 33.91 \\
Kettle Lake 3 & October 17, 2019 & $6,485.29$ & $6,485.30$ & 47.14 \\
Non-Potable Reservoir 1 & November 15, 2019 & $6,568.24$ & $6,568.25$ & 102.36 \\
Non-Potable Reservoir 2 & November 12, 2019 & $6,895.64$ & $6,895.65$ & 309.14 \\
Non-Potable Reservoir 3 & November 13, 2019 & $6,958.78$ & $6,958.79$ & 113.04 \\
Non-Potable Reservoir 4 & November 14, 2019 & $7,187.65$ & $7,187.66$ & 4.50 \\
\hline
\end{tabular}

Global Navigation Satellite System to collect elevation data at and above the water surface and up to the elevation of the dam or spillway at the time of the surveys. The topographic and bathymetric datasets were imported into Esri ArcMap 10.7.1. The combined survey points were then interpolated into digital elevation models, which were used to determine lake or reservoir volumes corresponding to water-surface elevations between the lakebed and the approximate top of the dam or spillway.

\section{References Cited}

Blue Marble Geographics, Inc., 2020, Global mapper: Hallowell, Maine, Blue Marble Geographics, Inc., 4 p., accessed on February 4, 2020, at https://www.bluemarblegeo.com/docs/ brochures/global-mapper-21-en.pdf.

Esri, 2020, ArcGIS-A complete integrated system: Redlands, Calif., Esri, accessed on February 3, 2020, at https://www.esri.com/en-us/arcgis/about-arcgis/overview.

Fisher, P.F., and Tate, N.J., 2006, Causes and consequences of error in digital elevation models: Progress in Physical Geography, v. 30, p. 467-489. [Also available at https://journals. sagepub.com/doi/pdf/10.1191/0309133306pp492ra.]

Garmin International, Inc., 2020, GPS 18x technical specifications: Olathe, Kans., Garmin International, Inc., 384 p., accessed on February 4, 2020, at https://static.garmincdn. com/pumac/GPS_18x_Tech_Specs.pdf.

Kohn, M.S., and Hempel, L.A., 2020, Survey and bathymetric data of Deadmans Lake, Golf Course Reservoir 9, Ice Lake, Kettle Lakes 1-3, and Non-Potable Reservoirs 1-4 at the
U.S. Air Force Academy, Colorado, 2019 (ver. 1.1, June 2020): U.S. Geological Survey data release, https://doi. org/10.5066/P9LTH0RO.

National Institute of Standards and Technology, 2020, U.S. survey foot: National Institute of Standards and Technology web page, accessed on January 31, 2020, at

https://www.nist.gov/pml/us-surveyfoot.

Rydlund, P.H., Jr., and Densmore, B.K., 2012, Methods of practice and guidelines for using survey-grade global navigation satellite systems (GNSS) to establish vertical datum in the United States Geological Survey: U.S. Geological Survey Techniques and Methods, book 11, chap. D1, 102 p. with appendixes, accessed on February 3, 2020, at https://pubs.usgs.gov/tm/11d1/.

Seafloor Systems, Inc., 2020, HydroLite-TM ${ }^{\mathrm{TM}}$ single frequency echosounder kit data sheet: Shingle Springs, Calif., Seafloor Systems, Inc., 2 p., accessed on February 3, 2020, at https://90bad3e4-1784-40fb-a37b-2016d39a0b4d.filesusr. com/ugd/7fd758_d87356a7c5554decaf7303091e4543f9.pdf.

Trimble Navigation Limited, 2020a, Trimble R10 GNSS system datasheet: Dayton, Ohio, Trimble Navigation Limited, 4 p., accessed on February 3, 2020, at http://trl.trimble.com/ docushare/dsweb/Get/Document-625158/022543-544E TrimbleR10_DS_1014_LR.pdf.

Trimble Navigation Limited, 2020b, Trimble TSC3 controller datasheet: Dayton, Ohio, Trimble Navigation Limited, 2 p., accessed on February 3, 2020, at https://geospatial.trimble. $\mathrm{com} /$ sites/geospatial.trimble.com/files/2019-03/Datasheet $\% 20$ -\%20Trimble\%20TSC3\%20Controller\%20-\%20English\%20 USL $\% 20-\% 20$ Screen.pdf. 
Trimble Navigation Limited, 2020c, Trimble R8 GNSS system datasheet: Dayton, Ohio, Trimble Navigation Limited, 2 p., accessed on February 3, 2020, at http://trl.trimble.com/ docushare/dsweb/Get/Document-140079/022543-079N TrimbleR8GNSS_DS_1014_LR.pdf.

Trimble Navigation Limited, 2020d, Trimble TDL450 series radio datasheet: Dayton, Ohio, Trimble Navigation Limited, 2 p., accessed on February 3, 2020, at https://cn.geospatial. trimble.com/sites/default/files/2019-03/Datasheet $\% 20-\% 20$ TDL $\% 20450 \mathrm{~L} \% 20$ and $\% 20$ TDL $\% 20450 \mathrm{H} \% 20$ Radio $\% 20$ -\%20English\%20USL\%20-\%20Screen.pdf.

Trimble Navigation Limited, 2020e, Trimble TSC2 controller datasheet: Dayton, Ohio, Trimble Navigation Limited, 2 p., accessed on February 3, 2020, at http://www.inlandgps.com/ Products/TSC2\%20Datasheet\%20200603.pdf.

U.S. Geological Survey, 2020, Colorado StreamStats: U.S. Geological Survey web page, accessed on January 31, 2020, at https://streamstats.usgs.gov/ss/.

Wilson, G.L., and Richards, J.M., 2006, Procedural documentation and accuracy assessment of bathymetric maps and area/ capacity tables for small reservoirs: U.S. Geological Survey Scientific Investigations Report 2006-5208, 24 p., accessed on February 3, 2020, at https://pubs.usgs.gov/sir/2006/5208/. 